\title{
LECITHOCERID FAUNA (MICROLEPIDOPTERA) FROM SIWALIKS OF NORTHWESTERN INDIA
}

\author{
P.C. Pathania ${ }^{1}$, H.S. Rose ${ }^{2}$, Rachita Sood ${ }^{3}$ and Amit Katewa ${ }^{4}$ \\ ${ }^{1}$ Dolphin (PG) College of Life Sciences, Chunni Kalan, Punjab 140 307, India \\ 2,3,4 Department of Zoology, Punjabi University, Patiala, Punjab 147002, India \\ Email: ${ }^{1}$ pathaniapc@yahoo.co.in
}

\begin{abstract}
In a survey on Lecithocerid moths from northwestern Siwaliks during November 1997 to November 2001, twenty-two species were collected and identified. Diagnosis, nomenclature aspects and distribution are presented in this paper.

KeYworDS

Inventory, Lecithoceridae, Lepidoptera, Siwaliks

Abbreviations

1A - First anal vein; $2 \mathrm{~A}$ - second anal vein; $3 \mathrm{~A}$ - third anal vein; CuA - first cubital vein; CuA - second cubital vein; Cup cubital posterior vein; $M_{1}$ - first median vein; $M_{2}$ - second median vein; $M_{3}$ - third median vein; $R_{1}$ - first anal vein; $R_{2}$ - second anal vein; $R_{3}$ - third anal vein; $R_{4}$ - fourth anal vein; $R_{5}-$ fifth anal vein; Rs - radial sector
\end{abstract}

The Siwaliks ranges mountain having elevation reaching upto $1500 \mathrm{~m}$ above m.s.l. extends from/bordered by river Kali in Uttaranchal to river Indus in Jammu and Kashmir (Chitkara, 1998) (Fig. 1). The authors have undertaken insect surveycum-collection tour to various localities in the region such as Kangra, Palampur, Dharamshala, Tanyhar, Sarkaghat, Baijnath, Andhretta, Solan, Dharampur, Nauni, Sabathu, Renuka lake, Nahan, Paunta Sahib (Himachal Pradesh), Jammu, Katra, Mansar Lake (Jammu \& Kashmir), Dehradun, Haridwar, Vikasnagar (Uttarakhand), Kalka, Pinjore (Haryana), Pathankot, Hoshiarpur, Dasua, Dhar, Roopnagar, Dunera, Mirzapur, Nawanshahar and Anandpur (Punjab) during different seasons between November, 1997 to November, 2001.

\section{Methodology}

The adults were collected during the night time with the help of portable light traps. Besides this, some specimens were also collected by hanging the source of light (125-Watt mercury vapour lamp) on a white sheet or white washed wall. The collected Lecitocerid moths were killed by using 1,1,2,2, tetrachloro ethane or ethyl acetate. The methodology discussed by workers such as Lindquist (1956), Tagestad (1974), Zimmerman (1978), Mikkola (1986) as well as Landry and Landry (1994) were followed for the pinning, stretching and preservation of specimens. The standard techniques given by Zimmerman (1978) and Robinson (1976) have been followed for wings and genitalia respectively. To write the taxonomic descriptions on various morphological characters (Robinson, 1976; Hodges, 1998; Park, 1995), wing venation (Zimmerman, 1978; Common, 1970) and external genitalia (Klots, 1970) were followed. Using a Camera Lucida attached to a stereoscopic light microscope drawn all illustrations. The coloured photographs of all the specimens were taken before dissection.

\section{OBSERVATIONS}

Earlier, Meyrick (1894,1905, 1907, 1908, 1908a, 1909, 1910, $1911,1912-1916,1913,1914,1916-1923,1923-1930,1930-$ 1936); Fletcher, (1929); Gaede (1937); Marchand (1947); Diakonoff (1952, 1954); Janse (1954), Clarke (1955,1965); Gozmány (1971, 1972, 1973, 1978); Nye \& Fletcher (1991); Park \& Omelko (1994); Robinson et al. (1994); Park \& Hodges (1995); Ueda (1995); Lovovsky (1996); Wu \& Park (1998, 1999, 1999a, 1999b, 1999c); Park (1999, 2000) and Park \& Heppner (2000) have made detailed studies on this group of insects. In this study, 22 species of Lecithoceridae have been recorded. Holotypes of the new species described under this study have been deposited in the Lepidoptera Laboratory, Department of Zoology, Punjabi University, Patiala.

\section{Superfamily: Gelechioidea \\ Diagnosis}

Vertex and frons decorated with smooth scales; labial palpus three segmented, upturned, third segment long, acute; forewing with veins $R_{4}+R_{5}$ stalked; hind tibia with dorsal surface furnished with long slender scales.

\section{Family: Lecithoceridae}

Lecithoceridae Le Marchand, 1947, Revue fr. Lepidopt., 11: 153 (as Lecithocerinae).

Type-genus: Lecithocera Herrich-Schäffer, 1853, Syst. Bearb. Schmett. Eur., 5: 11 (key), 45.

Diagnosis: Vertex and frons studded with smooth scaled; antenna longer than $3 / 4^{\text {th }}$ length of forewing; labial palpus long, upturned, second segment long, acute; forewing with Cup (expand this under Abbreviations) absent; hindwing with outer margin slightly excavated posterad of apex; male genitalia with uncus thorn-shaped, tapering to slender, acute apex or narrowed base and broad, bilobed apex; female genitalia with corpus bursae ovate or subovate in shape.

\section{Subfamily: Lecithocerinae}

Lecithocerinae Le Marchand, 1947, Revue Fr. Lepidopt., 11 : 153.

Timyridae Clarke, 1953, Cat. Type Specimens Microlepid. BMNH described by E. Meyrick, 1: 21.

Type-genus: Timyra Walker, 1864, List Secimens lepid. Insects Colln Br. Mus., 29: 782.

Type-genus: Lecithocera Herrich-Schaffer, 1853, Syst. Bearb. Schmett. Eur., 5: 11 (key), 45 pl.

Diagnosis: Uncus with narrow base and broad, bilboed apex and slender sclerite extending from base of tegumen to mesial surfae of valva, a strongly sclerotized bridge-like structure connecting tegumen and costa of valvae.

\section{Genus: Lecithocera Herrich-Schäffer}

Herrich-Schäffer, 1853, Syst. Bearb. Schmett. Eur., 5 : 11 [key], 45, pl.

Manuscript 1523; (C) ZOO; Date of publication 21 June 2007 Received 14 February 2006; Revised received 24 April 2007; Finally accepted 01 June 2007 
Microlepid. XII, figs 10, 11.

Quassitagma Gozmány, 1978, in Amsel. et al., Microlepid. Palaearctica, 5: 132. Type species : Frisilia indigens Meyrick, 1914, Supplta ent., 3: 50. Recontracta Gozmány, 1978, in Amsel et al., Microlepid. Palaearctica, 5: 148. Type species : Recontracta frisilina Gozmány, 1978, ibidem, 5: 149. Nyctocyrma Gozmány 1978, in Amsel et al., Microlepid. Palaearctica, 5: 149. Type species : Nyctocyrma fraudatrix Gozmány, 1978, ibidem., 5 : 151. Psammoris Meyrick, 1906, J. Bombay nat. Hist. Soc., 17: 149. Type species: Psammoris carpaea, Meyrick, 1906, ibidem., 17: 149.

Type-species: Carcina luticornella Zeller, 1839, Isis, Leipzing, 197, by monotypy.

Diagnosis: Vertex and frons covered with smooth scales; labial palpus long, upturned, second segment scaled, third segment long and acute; antenna long, filiform, longer than the length of forewing; metathoracic leg with hair like scales on hind tibia; forewing with veins $R_{3}+R_{4}+R_{5}$ arising from a common stalk, $R_{3}$ from base or near base of the stalk, $R_{4}$ to costa, $R_{5}$ to termen, CuA and $\mathrm{CuA}_{2}$ stalked or connate, however, the forewing venation with the stalk of $M_{2}$ and $M_{3}$ can not be a good separable character, because the venation is so variable with in genus (Park, 2000); hindwing with $R s+M_{1}$ stalked, $R s$ to costa, $M_{1}$ to termen, $M_{3}+C u A_{1}$ stalked. Male genitalia: uncus charac-teristically bilobed, setose; gnathos broader at base, apically pointed; vinculum $U$ or Vshaped; saccus absent; juxta bilobed apically; valvae elongated, cucullus broader or narrow, bearing setae or hair on the inner surface, ventrally with spiniform row of setae or without, a bridge-like sclerotized structure connecting costa and tegumen; aedeagus broad or small; vesica with multishaped cornutus present or absent. Female genitalia: papillae anales sparsely setose; anterior apophyses rod-like, basally broad, posterior apophyses thin; antrum present; corpus bursae long or small, broad or narrowed, ovate or subovate shaped; signum present or lacking.

\section{Lecithocera affusa Meyrick}

Lecithocera affusa Meyrick, 1923, Exot. Microlepid., 3: 40.

Material examined: 2 males, 2 females, 10.ix.1998; 2 males, 1 female, 11.ix.1998; 4 males, 11.ix.1999, 8 males, 12.ix.1999; 2 males, 13.ix.1999, University of Horticulture and Forestry, Nauni, Dist. Solan, Himachal Pradesh, 1360m; 2 males, 16.vi.1999; 8 males, 2 females, 16.vii.1999, Dharampur, Dist. Solan, Himachal Pradesh, $1200 \mathrm{~m}$, coll. P.C. Pathania.

Distribution: Khasi Hills (Assam) (Clarke, 1965); Nauni, Dharampur (Himachal Pradesh) (present work)

Larval host plant: Unknown

\section{Lecithocera gozmanyi Pathania and Rose}

Lecithocera gozmanyi Pathania and Rose, 2004, Geobios, 311: 228-229. Material examined:

Holotype: Male, 21.iv.1999, Forest Research Institute, Dehradun, Dist. Dehradun, Uttarakhand, $700 \mathrm{~m}$, coll. P.C. Pathania

Paratypes: 6 males, 21.iv.1999; 1 male, 22.iv.1999; 2 males, 2 females, 23.iv.1999; 3 males, 2 females, 25.iv.1999; 2 males, 19.iv.2000, Forest Research Institute, Dehradun, Dist. Dehradun, Uttarakhand, 700m; 2 males, 28.iv.1998, 2 males, 1 female, 29.ix.1998, Punjabi University, Dist. Patiala, Punjab, 250m, coll. P.C. Pathania and Rachita Sood.

Distribution: Dehradun (Uttarakhand), Patiala (Punjab) (present work) Larval host plant: Unknown

\section{Lecithocera aulias Meyrick}

Lecithocera aulias Meyrick, 1910, J. Bombay nat. Hist. Soc., 20: 447.

Material examined: 4 males, 2 females, 24.vi.1999; 3 males, 3 females, 25.vi.1999, Krishi Vishwavidyalaya, Palampur, Dist. Kangra, Himachal Pradesh, 700m, coll. P.C. Pathania.

Distribution: Khasi Hills (Assam) (Clarke, 1965); Palampur (Himachal Pradesh) (present work)

Larval host plant: Unknown

\section{Lecithocera semirupta Meyrick}

Lecithocera semirupta Meyrick, 1910, J. Bombay nat. Hist. Soc., 20 : 445. Material examined: 4 males, 3 females, 12.iv.1999; 2 males, 21.iv.2000, Renuka Lake, Dist. Sirmour, Himachal Pradesh, 740m, coll. P.C. Pathania

Distribution: Khasi Hills (Clarke, 1965); Renuka Lake (Himachal Pradesh) (present work)
Larval host plant: Unknown

\section{Lecithocera ianthodes Meyrick}

Lecithocera ianthodes Meyrick, 1931, Exot. Microlepid. 4: 80.

Material examined: 2 males, 1 female, 27.vi.1999, Norha Richard Holiday Home, Andhretta, Dist. Kangra, Himachal Pradesh, 900m; 3 males, 18.iv.2000; 3 males, 19.iv.2000, Forest Research Institute, Dehradun, Dist. Dehradun, Uttarakhand, $700 \mathrm{~m}$, coll. P.C. Pathania.

Distribution: Dehradun (India) (Clarke, 1965); Andhretta (Himachal Pradesh); Dehradun (Uttarakhand) (present work)

Larval host plant: Unknown

\section{Lecithocera immoblis Meyrick}

Lecithocera immoblis Meyrick, 1918, Exot. Microlepid., 2 : 103

Material examined: 1 male, 13.iii.1998; 1 male, 24.iii.1998;2 males, 25.iii.1998; 3 males, 30.iii.1999; 3 males, 8.iv.1999, 2 males, 29.iii.2000, Punjabi University, Patiala, Dist. Patiala, Punjab, 250m; 2 males, 24.vi.1998; 2 males, 25.vi.1999, Krishi Vishwavidyalaya, Palampur, Dist. Kangra, Himachal Pradesh, 700m;2 males, 24.ix.1999, 2 females, 19.iv.2000, Forest Research Institute, Dehradun, Dist., Dehradun, Uttarakhand, 700m; 4 males, 09.xi.2001, Jammu University Campus, Dist. Jammu, Jammu and Kashmir, 350m, coll. P.C.Pathania, Rachita Sood and Amit Katewa.

Distribution: Coimbatore (S.India) (Clarke, 1965); Patiala (Punjab); Palampur (Himachal Pradesh); Dehradun (Uttarakhand); Jammu (Jammu \& Kashmir) (present work)

\section{Larval host plant: Unknown}

\section{Lecithocera syntropha Meyrick}

Lecithocera syntropha Meyrick, 1918, Exot. Microlepid., 2 : 109.

Material examined: 2 males, 1 female, 27.vi.1999, Norha Richard Holiday Home, Andhretta, Dist. Kangra, Himachal Pradesh, 900m; 3 males, 18.iv.2000; 3 males, 19.iv.2000, Forest Research Institute, Dehradun, Dist. Dehradun, Uttarakhand, $700 \mathrm{~m}$, coll. P.C. Pathania.

Distribution: Quetta (N.W.India) (Clarke, 1965);Andhretta (Himachal Pradesh); Dehradun (Uttarakhand) (present work)

Larval host plant: Unknown

\section{Lecithocera choritis Meyrick}

Lecithocera choritis Meyrick, 1910, J.Bombay nat. Hist. Soc., 20: 448

Material examined: 2 males, 13.ix.1999; 2 males, 14.iv.1999, University of Horticulture and Forestry, Nauni, Dist. Solan, Himachal Pradesh, 1360m; 2 males, 24.vi.1999, Krishi Vishwavidyalaya, Palampur, Dist. Kangra, Himachal Pradesh, 700m, coll. P.C. Pathania.

Distribution: India, Palni Hills, Nilgiri Hills (Meyrick, 1910); Nauni, Palampur (Himachal Pradesh) (present work)

Larval host plant: Unknown

\section{Lecithocera metacausta Meyrick}

Lecithocera metacausta Meyrick, 1910, J. Bombay nat. Hist. Soc., 20 : 446. Material examined: 3 males, 11.ix.1999; 2 males, 14.ix.1999; 1 male, 5.iv.2000, University of Horticulture and Forerstry, Nauni, Dist. Solan, Himachal Pradesh, 1360m, coll. P.C. Pathania.

Distribution: Khasi Hills (Assam) (Clarke, 1965); Nauni (Himachal Pradesh) (present work)

Larval host plant: Unknown

\section{Subfamily: Torodorinae}

Torodorinae Gozmány, 1978, in Amsel et al., Microlepid. Palaearctica, 5: 189.

Type-genus: Torodora Meyrick, 1894, Trans. ent. Soc. Lond., 16.

Diagnosis: Male genitalia with uncus thorn-shaped, tapering to slender, acute apically, without a strongly sclerotized bridge-like structure connecting tegumen and costa of valvae.

\section{Genus: Hygroplasta Meyrick}

Hygroplasta Meyrick, 1925, in Wytsman,Genera Insect., 184 : 5 [key], 244. Type-species: Gelechia spoliatella Walker, 1864, List Specimens lepid. Insects Colln Br. Mus., 29: 659. 
Key to the subfamilies of the family Lecithoceridae

1. Uncus bilobed, a bridge-like structure connecting tegumen and valvae in male genitalia present Lecithocerinae

(GENUS: Lecithocera Herrich-Schäffer)

1A. Uncus simple, lacking the bridge-like structure connecting tegumen and valvae lacking in male

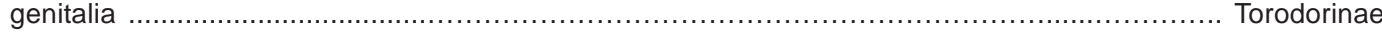

(GENERA: Hygroplasta Meyrick, Philoptila Meyrick, Torodora Meyrick)

Key to the species of the genus Lecithocera Herrich-Schäffer

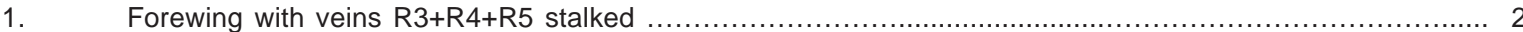

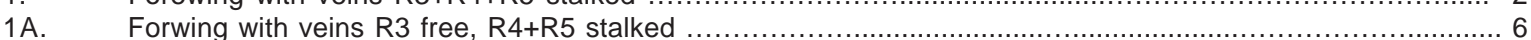

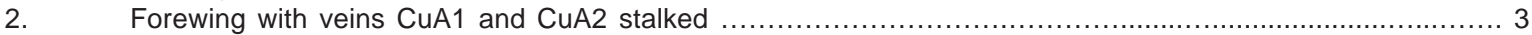

2A. Forewing with veins CuA1 and CuA2 not stalked (connate or free) ................................................. 4

3. Forewing with veins $\mathrm{CuA1}$ and $\mathrm{CuA2}$ on a longer stalk; male genitalia with saccular margin of each valva irregular, aedeagus curved, vesica without cornutus; female genitalia with anterior apophyses shorter and

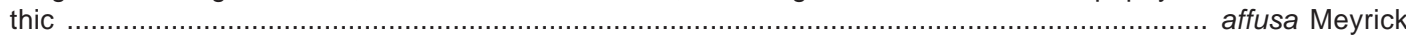

3A. Forewing with veins CuA1 and CuA2 on a shorter stalk, male genitalia with saccular margin of each valva relatively regular, produced into a spatulate structure, aedeagus straight, vesica armed with a arrow head and Y-shaped cornuti; female genitalia with anterior apophyses relatively longer and thin

gozmanyi Pathania and Rose

4. Hindwing with stalk of veins $M 3$ and CuA1 long, almost 2/3rd length of vein; forewing with vein CuA1 and CuA2 connate; female genitalia with anterior and posterior apophyses almost equal in length; corpus bursae large and broad vesica with Yshaped cornuti on the aedeagus .......................................................... aulias Meyrick

4A. Hindwing with stalk of veins M3 and CuA1 short, less than 1/5th of the vein; forewing veins CuA1 and CuA2 wide apart, basally; female genitalia with anterior apophyses always shorter than posterior apophyses, corpus

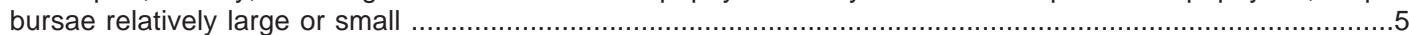

5. Hindwing with discocellulars poorly developed, stalk of veins Rs+M1 long; male genitalia with valva almost irregular or leaf-like, saccular margin straight, uncus slightly notched; female genitalia corpus bursae broad, signum rounded ................................................................................................ . semirupta Meyrick

5A. Hindwing with discocellulars relatively better developed, stalk of veins Rs+M1 short; male genitalia with valva elongated, saccular margin convex, uncus deeply notched; female genitalia corpus bursae small, signum spinde-shaped ianthodes Meyrick

6. Forewing with vein R3 from before anterior angle of discal cell, alar expanse 16-17mm; juxta almost excurved anteriorly; each valva more or less rectangular, aedeagus with one of the walls fringed with conspicuous hair immobilis Meyrick

6A. Forewing with vein R3 from anterior angle of discal cell, alar expanse 14-24mm; juxta not as above; each valva broadly triangular or rectangular, aedeagus with both the walls smooth ............................................. 7 Hindwing with veins $\mathrm{M} 3+\mathrm{CuA} 1$ on a longer stalk; forewing with veins CuA1 and CuA2 widely spaced after stalk; aedeagus long, longer than each valva, slighly bent at $2 / 5$ th from base, gradually curved, vesica beset with two long plate and two sigmoid shaped cornuti ................................................... syntropha Meyrick

7A. Hindwing with veins M3+CuA1 a shorter; forewing with veins CuA1 and CuA2 narrowly spaced after stalk; aedeagus relatively shorter slender, less arched, not bend as above, vesica beset with slit-like or tear drop like cornuti

8. Alar expanse 21-24mm; forewing light fuscous in colour; hindwing with vein CuP represented near anal margin; male genitalia with costa convex at base, then slightly concave, vesica with tear shaped or one Y-shaped cornuti present in aedeagus ....................................................................................... choritis Meyrick

8A. Alar expanse $14-15 \mathrm{~mm}$; forewing half longitudinally yellowish from base to apex, white towards costa; hindwing with vein CuP strongly present; male genitalia costa slightly convex, vesica with slit-like cornuti present in aedeagus metacausta Meyrick

Diagnosis: Vertex and frons decorated with smooth scales; labial palpus long, upturned, second segment beset with scales, third segment long and acute; antenna long, filiform, almost equal to the length of forewing; metathoracic leg with small hair like sacles on hind tibia; forewing with two black spots on discocellular or discal cell, distingusable or indistingusable, veins $R_{4}+R_{5}$ stalked, $R_{3}$ absent, CuA and CuA stalked; hindwing with vein $R s+M_{1}$ stalked, Rs to costa, $M_{1}$ to termen, $M_{3}$ and $C u A_{1}$ connate. Male genitalia: uncus characteristically long, pointed at apex; socii absent; gnathos hooklike, tegumen hood-like; valvae simple, dorso-distally pointed; saccus present, long or small, vesica with cornutus present or lacking. Female genitalia: papillae anales small in size; anterior apophyses broader at base; ductus burse long or small, sclerotized; ductus seminalis enter in corpus bursae; corpus bursae ovate or subovate shaped; signum present.

\section{Hygroplasta spoliatella (Walker)}

Gelechia spoliatella Walker, 1864, List Specimens lepid. Insects Colln Br. Mus., 29: 659

Material examined: 1 male, 5.ix.1999, Tanyhar, Dist. Mandi, Himachal Pradesh, $1120 \mathrm{~m}$, coll. P.C.Pathania

Distribution: Sri Lanka (Wu and Park, 1998); Tanyhar (Himachal Pradesh) (present work)

Larval host plant: Unknown

\section{Hygroplasta chunshengi Pathania and Rose}

Hygroplasta chunshengi Pathania and Rose, 2004, SHASHPA, 11(2): 94-96. Material examined:

Holotype: Male, 13.ix.1999, University of Horticulture and Forestry, Nauni, Dist. Solan, Himachal Pradesh, 1360m, coll. P.C. Pathania

Paratypes: 1 males, 5.ix.1999, Renuka Lake, Dist. Sirmour, Himachal Pradesh, 
740m; 1 males, 13.ix.1999, University of Horticulture and Forestry, Nauni, Dist. Solan, Himachal Pradesh, 1360m; 1 male, 16.ix.1999, Dharampur, Dist. Solan, Himachal Pradesh, 1500m; 2 males, 19.iv.2000, Forest Research Institute, Dehradun, Dist. Dehradun, Uttarakhand, $700 \mathrm{~m}$, coll. P.C. Pathania. Distribution: Nauni, Dharampur, Renuka Lake (Himachal Pradesh); Dehradun (Uttarakhand) (present work)

Larval host plant: Unknown

\section{Hygroplasta lygaea (Meyrick)}

Pachnistis lygaea Meyrick, 1911, J. Bombay nat.. Hist. Soc., 20: 707. Material examined: 2 males, 2 females, 10.ix.1998; 1 male, 11.ix.1998; 2 males, 13.ix.1998; 2 males, 1 females, 11.ix.1999; 3 males, 12.ix.1999; 19 males, 4 females, 13.ix.1999; 3 males, 2 females, 14.ix.1999, University of Horticulture and Forestry, Nauni, Dist. Solan, Himachal Pradesh, 1360m; 3 males, 16.vii.1999, Dharampur, Dist. Solan, Himachal Pradesh, 1500m; 3 males, 25.vi.1999, Krishi Vishwavidyalaya, Palampur, Dist. Kangra, Himachal Pradesh, 700m; 3 males, 19.iv.2000, Forest Research Institute, Dehradun, Dist. Dehradun, Uttarakhand, 700m; 2 males, 3 females, 09.xi. 2001, Jammu University Campus, Dist. Jammu, Jammu and Kashmir, 350m, coll. P.C. Pathania, Rachita Sood and Amit Katewa.

Distribution: Dalhousie, Kashmir (Meyrick, 1910); Nauni, Dharampur, Palampur (Himachal Pradesh); Dehradun (Uttarakhand); Jammu (Jammu \& Kashmir) (present work)

Larval host plant: Unknown

\section{Genus: Philoptila Meyrick}

Philoptila Meyrick, 1918, Exot. Microlepid., 2: 111.

Type-species: Philoptila effrenata Meyrick, 1918, ibidem., 2: 111.

Diagnosis: Vertex and frons decorated with smooth scales; labial palpus long, upturned, second segment with smooth scales, third segment long and acute; antenna long, filiform, almost equal to the length of forewing; metathoracic leg with small hair on hind tibia; forewing with veins $R_{3}+R_{4}+R_{5}$ stalked, arising from a common stalk at angle of discal cell; hindwing with veins Rs+M stalked, $M_{2}$ absent, $M_{3}+C u A_{1}$ stalked, $1 A+2 A$ forked at base. Male genitalia: uncus thorn-like, apex pointed; socii absent; gnathos broader at base, pointed at apex; valvae small, large and broad, cucullus inner surface densely setose, apically rounded or irregular; aedeagus long and broad; vesica with small or long cornutus present.

\section{Philoptila sp.}

Material examined: 2 males, 3.iv.1998; 2 males, 10.ix.1998;2 males, 24.xi.1998; 2 males, 25.xi.1998; 1 male, 13.x.1999; 2 males, 14.x.1999; 1 male, 30.ix.1999, Punjabi University, Patiala, Dist. Patiala, Punjab, 250m; 2 males, 5.iv.2000, University of Horticulture and Forestrt, Nauni, Dist. Solan, Himachal Pradesh, $1360 \mathrm{~m}$, coll. P.C. Pathania.

Distribution: Patiala (Punjab); Nauni (Himachal Pradesh) (present work) Larval host plant: Unknown.

\section{Genus: Torodora Meyrick}

Torodora Meyrick, 1894, Trans. ent. Soc. Lond., : 16.

Habrogenes Meyrick 1918, Exot. Microlepid., 2: 102.

Type-species: Lecithocera eupatris Meyrick, 1910, J. Bombay nat. Hist.
Soc., 20: 443.

Brachmia Hübner (1825) 1816, Vertz. bekannter. Schmett. : 419. Type species: Tinea dimidiella [Dennis \& Schiffermülar], 1775 Ankündung syst. Werks Schmett. Wienergegend,: 141

Panplatyceros Diakonoff, 1951, Ark. Zool, 3: 76. Type specis : Panplatyceros serpentina Diakonoff, 1951, Ark. Zool. 3: 76.

Type-species: Torodora characteris Meyrick, 1894, Trans. ent. Soc. Lond., 16. Clarke, 1955, Cat.Type Specimens Microlepid. BMNH described by E. Meyrick, 1:21.

Diagnosis: Vertex and frons covered with smooth scales; labial palpus long, upturned, second segment with small scales, third segment long and acute; antenna long, filiform, longer than $3 / 4^{\text {th }}$ length of forewing; metathoracic leg with hair-like scales on hind tibia; forewing relatively broad, apex rounded, termen slightly sinuate; vein $M_{1}$ arising far from stalk of $R_{3}+R_{4}+R_{5}, M_{1}$ and $M_{2}$ parallel; $\mathrm{M}_{2}$ and $\mathrm{M}_{3}$ free, $\mathrm{CuA}_{1}$ and $\mathrm{CuA}_{2}$ stalked, cell closed; hindwing much broader than forewing, Rs $+\mathrm{M}_{1}$ stalked, Rs to costa or apex, $\mathrm{M}_{3}+\mathrm{CuA}$ connate or stalked; however, the venation of both wings do not quite agree in all species of the genus Torodora, especially in the condition of $M_{2}$ and $M_{3}$ on the forewings and $M_{3}$ and $C u A_{1}$ on hindwings; (1) $M_{2}$ and $M_{3}$ free on the forewing, $\mathrm{M}_{3}$ and $\mathrm{CuA}$ also free on the hindwing, as in the type-species, characteris Meyrick; (2) $M_{2}$ and $M_{3}$ stalked near base on forewing and $M_{3}+C u A_{1}$ stalked near $1 / 5^{\text {th }}$ on hindwing; (3) $M_{2}$ and $M_{3}$ stalked near middle on forewing, $M_{3}$ and CuA stalked before middle in hindwing; (4) $M_{2}$ and $M_{3}$ stalked near middle on the forewing, $\mathrm{M}_{3}+\mathrm{CuA}$, stalked near or beyond middle on the hindwing. Male genitalia: uncus simple, thorn-like or broad, broader basally, socii absent; gnathos beak-like, broader at base, sclerotized, apex pointed; saccus absent; valvae broad, cucullus with tuft of long hair or without, inner surface setose, ventrally with spiniform setae or without; aedeagus broad; vesica with or without cornotus. Female genitalia: anterior apophyses rod-like, broader at base; ostium bursae centrally placed; antrum present; ductus seminalis open at midle of ductus bursae; corpus bursae ovate or subovate shaped; signum present.

\section{Torodora parafuscoptera Rose and Pathania}

Torodora parafuscoptera Rose and Pathania, 2003, Bioved, 14 (1,2): 143144

Material examined:

Holotype: Male, 21.iv.1999, Forest Research Institute, Dehradun, Dist. Dehradun, Uttarakhand, $700 \mathrm{~m}$, coll. P.C. Pathania

Paratypes: 2 males, 2 females, 21.iv.1999; 2 males, 22.iv.1999; 2 males, 25.iv.1999; 1 male, 23.ix.1999; 1 male, 18.iv.2000; 3 males, 19.iv.2000, Forest Research Institute, Dehradun, Dist. Dehradun, Uttarakhand, 700m, coll. P.C. Pathania.

Distribution: Dehradun (Uttarakhand) (present work)

Larval host plant: Unknown

\section{Torodora pubesensovalvata Rose and Pathania}

Torodora pubesensovalvata Rose and Pathania, 2003, Bioved, 14 (1-2): 144-146.

Material examined:

Holotype: Male, 12.iv.1999, Renuka Lake, Dist. Sirmour, Himachal Pradesh, 740m, coll. P.C. Pathania

\section{Key to the species of the genus Hygroplasta Meyrick}

1. Alar expanse $23 \mathrm{~mm}$; dorsal surface of forewing with discocellular spot rounded and more clear, another indistinguishable spot present in discal cell; male genitalia with valvae broad, saccus moderately long, aedeagus long, straight, bent near apex, apex acute .................................................................. spoliatella Walker

1A. Alar expanse 18-22mm; dorsal surface of forewing with discocellular spot relatively more prominent, discal cell with spot prominent; male genitalia with valvae small, saccus long or small, aedeagus relatively long or small.....2

2. Male genitalia with saccus very long, uniformly broad throughout, sacculus margin convex basally then straight, costa convex medially, aedeagus long, vesica without cornutus; female genitalia with ductus bursae open at middle of corpus bursae, signum rounded chunshengi Pathania and Rose

2A. Male genitalia with saccus relatively smaller, broader distally, sacculus margin concave medially, costa concave medially, aedeagus short, vesica with cornutus; female genitalia with ductus bursae open near middle of corpus bursae, signum spinde-shaped lygaea Meyrick 
Paratypes: 3 males, 2 females, 12.iv.1999; 2 males, 13.iv.1999; 2 males, 3.ix.1999; 2 males, 5.ix.1999, Renuka Lake, Dist. Sirmour, Himachal Pradesh, $740 \mathrm{~m}$, coll. P.C.Pathania.

Distribution: Renuka Lake (Himachal Pradesh) (present work) Larval host plant: Unknown

\section{Torodoro ponomarenkoae Rose and Pathania}

Torodoro ponomarenkoae Rose and Pathania, 2003, Bioved, 14 (12): 146148.

Material examined:

Holotype: Male, 11.ix.1998, University of Horticulture and Forestry, Nauni, Dist. Solan, Himachal Pradesh, $1360 \mathrm{~m}$, coll. P.C. Pathania

Paratypes: 1 male, 11.ix.1998; 4 males, 12.ix.1999; 2 males, 13.ix.1999; 1 male, 11.ix.1999, University of Horticulture and Forestry, Nauni, Dist. Solan, Himachal Pradesh, $1360 \mathrm{~m}$, coll. P.C. Pathania.

Distribution: Nauni (Himachal Pradesh) (present work)

Larval host plant: Unknown

\section{Torodora nyctiphron (Meyrick)}

Lecithocera nyctiphoran Meyrick, 1931, Exot. Microlepid., 4: 81.

Material examined: 4 males, 5.ix.1999, Tanyhar, Dist. Mandi, Himachal Pradesh, $1120 \mathrm{~m}$, coll. P.C. Pathania.

Distribution: Sikkim, Gangtok (Clarke, 1965); Tanyhar (Himachal Pradesh) (present work)

Larval host plant: Unknown

\section{Torodora fuscoptera Rose and Pathania}

Torodora fuscoptera Rose and Pathania, 2003, Bioved, 14(1,2): 148-151.

Material examined:

Holotype: Male, 11.ix.1998, University of Horticulture and Forestry, Nauni, Dist.Solan, Himachal Pradesh, 1360 m, coll. P.C. Pathania

Paratypes: 12 males, 11.ix.1998; 9 males, 11.ix.1999; 6 males, 12.ix.1999; University of Horticulture and Forestry, Nauni, Dist. Solan, Himachal Pradesh, 1360m; 3 females, 16.vi.1999; 2 females, 16.vii.1999; 1 female, 14.ix.1999, Dharampur, Dist. Solan, Himachal Pradesh, $1500 \mathrm{~m}$, coll. P.C. Pathania.

Distribution: Nauni, Dharampur (Himachal Pradesh) (present work)

Larval host plant: Unknown

\section{Torodora parasema (Meyrick)}

Brachmia parasema Meyrick, 1913, Exot. Microlepid., 1: 66.

Material examined: 2 males, 13.iv.1999, Renuka Lake, Dist. Sirmour, Himachal Pradesh, 740m; 3 males, University of Horticulture and Forestry, Nauni, Dist. Solan, Himachal Pradesh, 1360m, coll. P.C. Pathania.

Distribution: Bengal, Pusa (Clarke, 1965); Renuka Lake, Nauni (Himachal Pradesh) (present work)

Larval host plant: Unknown

\section{Torodora fortis (Meyrick)}

Lecithocera fortis Meyrick, 1918, Exot. Microlepid., 2 : 111

Material examined: 4 males, 14.ix.1999, Dharampur, Dist. Solan, Himachal Pradesh, $1500 \mathrm{~m}$, coll. P.C. Pathania

Distribution: Nilgiri Hills (India) (Clarke, 1965); Dharampur (Himachal Pradesh) (present work)

Larval host plant: Unknown

\section{Torodora deltospila (Meyrick)}

Lecithocera deltospila Meyrick, 1911, J. Bombay nat. Hist. Soc., 20: 706.

Material examined: 1 male, 12.iv.1999; 2 males, 14.iv.1999; Renuka Lake, Dist. Sirmour, Himachal Pradesh, 740m; 1 male, 6.vii.1999, Tanyhar, Dist. Mandi, Himachal Pradesh, 1120m; 1 male, 23.ix.1999; 2 males, 18.iv.2000, Forest Research Institute, Dehradun, Dist. Dehradun, Uttarakhand, 700m; 3 males, 09.xi.2001, Jammu University Campus, Dist. Jammu, Jammu and Kashmir, 350m, coll. P.C. Pathania, Rachita Sood and Amit Katewa.

Distribution: Khasi Hills (Assam) (Clarke, 1965); Renuka Lake, Tanyhar (Himachal Pradesh); Dehradun (Uttarakhand); Jammu (Jammu \& Kashmir) (present work)

Larval host plant: Unknown

\section{Torodara neodeltospila Rose and Pathania}

Torodara neodeltospila Rose and Pathania, 2003, Bioved, 14(1,2): 152-155. Material examined:

Holotype: Male, 13.iv.1999, Renuka Lake, Dist. Sirmour, Himachal Pradesh, $740 \mathrm{~m}$, coll. P.C. Pathania

Paratypes: 1 male, 13.iv.1999; 2 males, 4.ix.1999, Renuka Lake, Dist. Sirmour, Himachal Pradesh, 740m; 1 male, 10.ix.1998, University of Horticulture and Forestry, Nauni, Dist. Solan, Himachal Pradesh, 1360m; 2 males, 25.vi.1999, Krishi Vishwavidyalaya, Palampur, Dist. Kangra, Himachal Pradesh, 700m, coll. P.C. Pathania

Distribution: Renuka Lake, Nauni, Palampur (Himachal Pradesh) (present work)

Larval host plant: Unknown

\section{Discussion}

According to Park (1999), "the taxonomic status of the family Lecithoceridae has not been well defined, due to various differing opinions as to its rank". Marchand (1947) proposed the subfamily Lecithocerinae with Lecithocera Herrich-Schäffer as the type-genus, which was placed under the family Gelechiidae by Diakonoff (1954) and Janse (1954). In a recent publication, Park (1999) has stated, "there is no doubt that it should be considered as a family rank by such autapomorphic characters, as antenna being longer than forewing length (except Oditinae established by Lovovsky, 1996) and gnathos always bent downwardly." Gozmány (1978) established three new subfamilies under Lecithoceridae i.e., Lecithocerinae Le Marchand (based on the genus Lecithocera Herrich-Schäffer), Ceuthomadarine Gozmány (based on the Ceuthomadarus Gozmány), and Torodorinae Gozmány (based on the genus Torodora Meyrick). The subfamily Lecithocerinae has the distinction of having a bridge-like structure connecting the tegumen and costa of the valvae in the male genitalia, whereas, in the Torodorinae these structures are wanting. Lecithocera is awidely distributed genus having sixty-two species listed under it from India (Gaede, 1937). Though, the venation is somewhat variable in this genus yet, various species can be adequately put under it in view of totality of characters, particularly the genitalic characters.

In subfamily Torodorinae, three genera i.e, Hygroplasta Meyrick, Philoptila Meyrick and Torodora Meyrick were studied. Meyrick (1925) proposed the genus Hygroplasta with Gelechia spoliatella Walker as its type-species kept the same in the family Gelechiidae. However, Clarke (1965) transferred the genus from the latter family to the family Lecithoceridae, under which it is being dealtwith presently. It has been observed that different individuals of this genus complex may have one or two black spots on the wings, which may be conspicuous, faint or even obscure. The genus Philoptila was proposed with $P$. effrenata Meyrick as its type-species by Meyrick (1918). Its diagnosis was based on a single male specimen collected from Kanara (southern India). Clarke (1965) has furnished a photograph of its male genitalia and a line drawing of the wing venation. While doing so, the author has also stated that, "the type was destroyed after photography and palpus are not available for illustration". The genus, under reference, is conspicuous in having the veins $R_{s}, R_{4}, R_{5}$ and $M_{1}$, $\mathrm{CuA}_{1}, \mathrm{CuA}_{2}$ stalked in the forewing, whereas, the vein $\mathrm{M}_{2}$ is wanting in the hindwing. The genus has been listed under the family Gelechiidae (spelled as Gelechiadea) and 
Lecithoceridae by Fletcher (1929) and Clarke (1965) respectively.

Meyrick (1894) proposed the genus Torodora with $T$. characteris Meyrick as its type-species and included it in the family Gelechiidae (Fletcher, 1929). However, Clarke (1955) considered it under the family Lecithoceridae (Nye and Fletcher, 1991). On the contrary, with Torodora Meyrick as its type-genus, Gozmány (1978) proposed a new subfamily Torodorinae under the family Lecithoceridae. Recently, Wu and Park (1999) have mentioned that the latter family contains about eight hundred species spread over in about one hundred genera worldwide. However, according to Park and Heppner (2000), the genus Torodora Meyrick possesses about 85 species, out of which 82 belong to the Oriental, two to Palaearctic and one to the Ethopian regions. While revising the diagnosis of the genus under reference, though the aforesaid workers have given due emphasis to the structure of the wing venation, it has been stated that the venation of both wings do not quite agree in all species of the genus Torodora especially in the condition of $\mathrm{M}_{2}$ and $\mathrm{M}_{3}$ on the forewings and $\mathrm{M}_{3}$ and $\mathrm{CuA}$ on the hindwings. Due to the inconsistency in the wing venation, Wu and Park (1999) have framed separate keys for interspecific discrimination of the males and females of the same species on the basis of their respective genitalia. Similarly, Park and Heppner (2000) proposed two keys to sort out the species of the genus Torodora from Taiwan did not use venation for specific discrimination due to this inconsistency. One of the keys formulated by then was on the basis of the wing maculation, hind tibia and wing shape and the other on the basis of the male genitalia only. Somehow or the other, the female genitalia has not been discussed at all. In addition to this, these authors have also segregated/placed all the seven species from Taiwan into four groups. They have also recorded distributional range of the genus from India to Southeast Asia, including Burma. Prior to this, Gozmány (1972) has also dealtwith some Lecithocerid genera i.e., Aproparia, Parrhasastris, Rhyparomatrix besides eleven new species combinations under the genus Torodora after shifting them from the genus Lecithocera Herrich-Schäffer. Being true Torodora, a thorough examination of the male genitalia reveals that the costal bridgelike structure connecting the tegumen and the valvae in the male genitalia is wanting and the uncus is always present and well developed (more or less thorn-like in lateral view) in all the taxomonomic treated nine species of this genus.

\section{REFERENCES}

Chitkara, M.G. (1998). Encyclopaedia of Ecology, Environment and Pollution 6: 1339.

Clarke, J.F.G. (1955). Catalogue of the type specimens of Microlepidoptera in the British Mus. (Natural History) described by Edward Meyrick, Vol. I. Trustees of the British Museum (Natural History), London, 332pp.

Clarke, J.F.G. (1965). Catalogue of the type specimens of Microlepidoptera in the British Mus.(Natural History) described by Edward Meyrick, Vol. V. Trustees of the British Museum (Natural History), London, 581pp.

Common (1970). Lepidoptera, The insects of Australia, chapter 36, CSIRO, Divn. Entomology, Melbourne, 1029pp.

Diakonoff, A. (1952). Entomological results of Swedish expedition 1934 to Burma and British India. Lepidoptera collected by R. Malaise. Microlepidoptera 1. Arkiv for Zoologi 3: 73-79.

Diakonoff, A. (1954). Consideration on the terminology of the genitalia in
Lepidoptera. Lepidoptera News 8(3-4): 67-74.

Fletcher, T.B. (1929). A list of the generic names used for Microlepidoptera. Memoirs of the Department of Agriculture in India (Entomological) Series, 11, ix+246pp. Gaede, M. (1937). Catalogue of Gelechiidae. Lepidopterorum catalogus 79: 1630 Gozmány, L.A. (1971). Notes on Lecithoccerid taxa (Lepidoptera) I. Acta Zoologica Hungarica 17(3-4): 251-254.

Gozmány, L.A. (1972). Notes on Leithocerid taxa (Lepidoptera) II. Acta Zoologica Hungarica 18(3-4): 291-296.

Gozmány, L.A. (1973). Symmocid and Lecithocerid moths (Lepidoptera) from Nepal. Khumbu Himal 4 : 413-444.

Gozmány, L.A. (1978). Lecithoceridae. 126-132. In: Amsel, H.G., F. Gregor \& H. Reisser (eds.), Microlepidoptera Palaearctica, part 5. Verlag Georg Fromme \& Co., Vienna, xxvii+306pp., 93pls.

Hodges, R.W. (1998). Gelechioidea, pp.131-158. In: Kristensen, N.P. (Ed.). Lepidoptera, Moths and Butterflies 1 - Handbuch der Zoologie/Handbook of Zoology. Handbook of Zoology IV/35. Walter de Gruyter, Berlin \& New York.

Janse, A.J.T. (1954). Gelechiidae. The Moths of South Africa 5(2): 332-384.

Klots, A.B. (1970). Taxonomists Glossary of Genitalia in Insects, pp.115-139. In: Lepidoptera. Munksgasard, Copenhagen.

Landry, J.F. \& B. Landry (1994). A technique for setting and mounting microlepidoptera. Journal of the Lepidopteran Society 48(3): 205-227.

Meyrick, E. 1905 Descriptions of Indian Microlepidoptera. Journal of the Bombay Natural History Society 16: 580-619.

Lindquist, O.H. (1956). A technique for pinning and spreading small microlepidoptera. Canadian Entomologist 138(1): 24-25.

Lovovsky, A.L. (1996). The diversity of the Oecophoridae fauna in the boreal and temporate zones of Eurasia (Lepidoptera). Acta Zoologica Fennica 200: 38. Marchand, L.S. (1947). Les Tineina Gelechiidae. Revne Francaise de Lépidopterologie. 11: 145-163.

Meyrick, E. (1894). On a collection of lepidoptera from upper Burma by Edward Meyrick. Transactions of the Entomological Society of London 1: 1-29.

Meyrick, E. (1905). Descriptions of Indian microlepidoptera. Journal of the Bombay Natural History Society 16: 580-619.

Meyrick, E. (1907). Descriptions of Indian microlepidoptera. Journal of the Bombay Natural History Society 17: 730-754, 976-994.

Meyrick, E. (1908). Descriptions of Indian microlepidoptera. Journal of the Bombay Natural History Society 18: 137-160, 437-460, 613-638, 806-832,

Meyrick, E. (1908a). New micro-lepidoptera from India and Burma. Records of Indian Museum 12: 3295-400.

Meyrick, E. (1909). Descriptions of Indian Microlepidoptera. Journal of the Bombay Natural History Society 19: 410-437, 582-607.

Meyrick, E. (1910). Descriptions of Indian microlepidoptera. Journal of the Bombay Natural History Society 20: 143-168, 435-462, 706-736.

Meyrick, E. (1911). Descriptions of Indian microlepidoptera. Journal of the Bombay Natural History Society 21: 104-131, 852-877.

Meyrick, E. (1912-1916). Exotic Microlepidoptera - 1. Marlborough, Wiltshire, 640pp,

Meyrick, E. (1913) Description of Indian microlepidoptera. Journal of the Bombay Natural History Society 22: 771-781.

Meyrick, E. (1914). Descriptions of Indian microlepidoptera. Journal of the Bombay Natural History Society 23: 118-130.

Meyrick, E. (1916-1923). Exotic Microlepidoptera - 2. Marlborough, Wiltshire, 640pp.

Meyrick, E. (1923-1930). Exotic Microlepidoptera - 3. Marlborough, Wiltshire, 640pp.

Meyrick, E. (1930-1936). Exotic Microlepidoptera - 4. Marlborough, Wiltshire, $642 \mathrm{pp}$.

Mikkola, K. (1986). Tower spreading, a handy method for provisional field preparation for microlepidoptera. Notulae Entomologicae. 66: 101-102.

Nye, I.W.B. \& D.S. Fletcher (1991). The Generic Names of Moths of the World. Natural History Museum Publication 6: 1-368.

Park, K.T. (1995). Gelechiidae of Taiwan 1. Review of Anarsia, with descriptions of four new species (Lepidoptera: Gelechioidea). Tropical Lepidoptera 6(1): 55-66. Park, K.T. (1999). Lecithoceridae (Lepidoptera) of Taiwan (1): Subfamily Lecithocerinae: Genera Homaloxestis Meyrick and Lecithocera Herrich-Schaffer. Zoological Studies 38(2): 238-256.

Park, K.T. (2000). A new species of Gelechiidae (Insecta, Lepidoptera) from Korea. Korean Journal of Systematic Zoology 16(2): 165-168. 
Key to the genera of the subfamily Torodorinae

1. Forewing upper surface with two black spots, vein R3 absent; male genitalia with vinculum produced anteriorly into a well developed saccus ................................................................... Hygroplasta Meyrick

1A. Forewing not as above, vein R3 present; male genitalia with vinculum without saccus ............................... 2

2. Forewing with veins $\mathrm{M} 3+\mathrm{CuA} 1+\mathrm{CuA} 2$ arising from common stalk at angle of cell; male genitalia with gnathos small, broad basally, apically pointed ............................................................................. Philoptila Meyrick

2A. Forewing with veins CuA1+CuA2 stalked; male genitalia with gnathos long, beak like .............. Torodora Meyrick

\section{Key to the species of the genus Torodora Meyrick}

1. Forewing without black streaks or black dots; male genitalia with gnathos well developed ......................... 2

1A. Forewing with black streaks or black dots; male genitalia with gnathos relatively less developed...................6

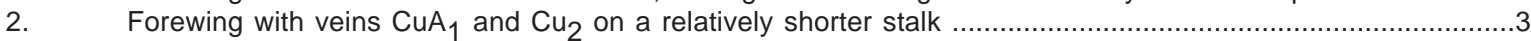

2A. Forewing with veins $\mathrm{CuA}_{1}$ and $\mathrm{CuA} \mathrm{A}_{2}$ comparatively on a longer stalk .................................................

3. Male genitalia with each valva elongated, broader at base, tapering in distal half, beset with small setae, vesica with cornuti present ......................................................................... parafuscoptera Rose and Pathania

3A. Male genitalia with each valva relatively smaller, distal half leaf like, not tapering, inner surface beset with a long hair directed anteriorly, vesica without cornutus....................................pubesensovalvata Rose and Pathania

4. Forewing with veins $\mathrm{M}_{2}$ and $\mathrm{M}_{3}$ connate; male genitalia with each valva sickle-shaped, vesica without definite cornuti in aedeagus .............................................................................. ponomarenkoae Rose and Pathania

4A. Forewing with veins $M_{2}$ and $M_{3}$ not connate, widely spaced; male genitalia with each valva not sickle-shaped,

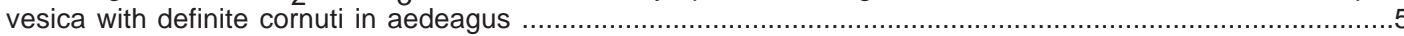

5. Hindwing with vein Rs reaching precisely on apex; male genitalia with valva with costa convex at base, then straight, cucullus small, furnished with very long hair-like setae, vesica with a row of needle-like cornuti present nyctiphron Meyrick

5A. Hindwing with vein Rs ending at costa near apex; male genitalia with valva with costa concave, cucullus broad, furnished with smaller setae, vesica with a triangularly shape cornutus present

fuscoptera Rose and Pathania

6. Forewing with veins $\mathrm{M}_{2}$ and $\mathrm{M}_{3}$ connate, veins $\mathrm{CuA}_{1}$ and $\mathrm{CuA}_{2}$ short stalked; male genitalia with each valva somewhat elongated, parallel sided ............................................................................................. 7

6A. Forewing with veins $\mathrm{M}_{2}$ and $\mathrm{M}_{3}$ not connate, widely spaced, veins $\mathrm{Cu} \mathrm{A}_{1}$ and $\mathrm{Cu} \mathrm{A}_{2}$ long stalked; male genitalia with valvae not as above

7. Alar expanse $14 \mathrm{~mm}$; forewing costal margin with two, broad, black unequal sized lines vertically present; male genitalia with each valva with costa straight, aedeagus long and broad, almost equal to the length of each valva, bent at $1 / 3$ rd basally ...parasema Meyrick

7A. Alar expanse $18 \mathrm{~mm}$; forewing costal margin with two, thin, black equal sized lines vertically present; male genitalia with each valva with costa curved, aedeagus small and narrowed, bent at middle

8. Hindwing with vein Rs to costa; male genitalia with each valva sickle-shaped, pointed apically, cuccullus narrowed, aedeagus with roundedapex ......................................................................... deltospila Meyrick

8A. Hindwing with vein Rs to apex; male genitalia with each valva sequesed in the basal half, expanded distally, cucullus broad, apically rounded, aedeagus with pointed apex ..................... neodeltospila Rose and Pathania

Park, K.T. \& J.B. Heppner (2000). Lecithoceridae (Lepidoptera) of Taiwan (III) Subfamily Torodrinae: genus Torodora Meyrick. Transaction of the Lepidopterological Society of Japan. 51(4): 287-297.

Park, K.T. \& M Omelko (1994). Two new species of Genus Stegasta (Lepidoptera, Gelechiidae). Japanese Journal of Entomology 62(4): 867-871.

Park, K.T. \& R.W. Hodges (1995). Gelechiidae (Lepidoptera) of Taiwan III. Systematic Revision of the genus Dichomeris in Taiwan and Japan. Insecta Koreana 12: $1-101$

Robinson, G.S. (1976). The preparation of slides of Lepidoptera genitalia with special reference to microlepidoptera. Entomological Gazette 27(2): 127-132. Robinson, G.S., K.R. Tuck \& M. Shaffer (1994). A Field Guide to the Smaller Moths of South-East Asia. Malaysian Nature Society, Malasia, 308pp+1-32pls. Tagestad, A.D. (1974). A technique for mounting Microlepidoptera. Journal of the Kansas Entomological Society 47: 26-30.

Ueda, T. (1995). The genus Helcystogramma (Lepidoptera, Gelechiidae) of Japan. Japanese Journal of Entomology 63(2): 377-387.

Wu, C. \& K.T. Park (1998). Taxonomic review of the family Lecithoceridae (Lepidoptera) from Sri Lanka IV. The subfamily Torodorinae: Genera Deltoplastis Meyrick, Hygroplasta Meyrick and Antiochtha Walker, Insecta Koreana 15: 1-22. Wu, C. \& K.T. Park (1999). Taxonomic review of the Lecithoceridae (Lepidoptera) in Sri Lanka IV. The subfamily Lecithocerinae: Genus Lecithocera Herrich-schaffer and its Allies. Insecta. Koreana 16(1): 114.

Wu, C. \& K.T. Park (1999a). Taxonomic review of the Lecithoceridae (Lepidoptera) in Sri Lanka IV. The subfamily Lecithocerinae: Genus Alciphanes and others. Insecta Koreana 16(2): 131-142

Wu, C. \& K.T. Park (1999b). A taxonomic review of the family Lecithoceridae (Lepidoptera) in Sri Lanka IV. The subfamily. Torodorinae: Genera Torodora and allies. Tinea 16(1): 61-72.

Wu, C. \& K.T. Park (1999c). A taxonomic review of the Lecithoceridae (Lepidoptera) in Sri Lanka V. The subfamily Lecithocerinae: Genera Timyra and Doxogenes. Korean Journal of Systematic Zoology 16(2): 205-220.

Zimmerman, E.C. (1978). Microlepidoptera. Insects of Hawaii, Vol. 9. University Press of Hawaii, Honololu. xviii+1903pp.

\section{ACKNOWLedGements}

The authors are thankful to the Ministry of Environment and Forests (GOI), New Delhi, for funding the project on moths and to the Vice Chancellor; Punjabi University, Patiala for providing facilities to run the Coordinating centre on Microlepidoptera under an All India Coordinated Project on Taxonomy (AICOPTAX). We also thank Dr. K.T. Park (Korea) for sending much needed literature and valuable suggestions during the course of these studies

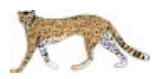

